\author{
Маркова Т.Д. \\ кандидат економічних наук, старший викладач \\ E-mail: markova.tetiana17@gmail.com
}

\author{
Стрепенюк М.M. \\ магістрант \\ E-mail: marina.strepenyuk@ukr.net
}

\author{
Римар Г.А. \\ магістрант \\ кафедра обліку та аудиту \\ Одеська національна академія харчових технологій \\ вул. Канатна, 112, м. Одеса, Україна, 65039 \\ E-mail: anna1995@te.net.ua
}

\title{
АСПЕКТИ ОБЛІКУ РОЗРАХУНКІВ 3 ПОКУПЦЯМИ ТА ЗАМОВНИКАМИ ЗА ГОТОВУ ПРОДУКЦІЮ В СУЧАСНИХ УМОВАХ
}

У статті розглядається сутність поняття «дебіторська заборгованість», «готова продукція», теоретичні та практичні аспекти організації обліку розрахунків з вітчизняними покупцями та замовниками за реалізацію готової продукції на підприємстві. На базі дослідження та узагальнення сформовано власну дефініцію понять «дебіторська заборгованість» та «готова продукція». Здійснено аналіз питомої ваги дебіторської заборгованості підприємств за економічних видом діяльності промисловість та обсяг реалізованої промислової продукції України. Визначено першочергові завдання дієвої організації обліку реалізації готової продукції покупцям та замовникам. Пропонується ведення аналітичного (індивідуального) обліку розрахунків з покупцями та замовниками, який викликаний різними строками дебіторської заборгованості та видом діяльності. Обґрунтовано ризик наданням комерційного кредиту, що зумовлює створення безнадійної дебіторської заборгованості.

Ключові слова: дебіторська заборгованість, облік розрахунків з покупцями та замовниками, готова продукція, безнадійна дебіторська заборгованість.

\section{This work is licensed under a Creative Commons Attribution 4.0 International License} http://creativecommons.org/licenses/by/4.0/

Постановка проблеми та її зв'язок з важливими науковими та практичними завданнями. Складність управління економікою підприємств в умовах нестабільного економічного, політичного та екологічного середовища, в якому вони функціонують, потребує ведення своєчасного обліку виробничо-господарської діяльності, особливо процес виробництва, реалізації готової продукції та розрахунків 3 покупцями та замовниками, що є основними економічними категоріями відповідно вимогам сучасності. Будь-яка продукція проходить декілька етапів, починаючи з виробництва та закінчуючи реалізацією їі на арені ринкових відносин.

Слід відмітити, що економічна ситуація в Україні завжди має напружену атмосферу діяльності, що спричинена нестабільними для розвитку економіки чинниками, а саме некерованими інфляційними процесами, прийнятими законодавчими нормативними актами, що деколи суперечать один одному, та іншими чинниками, які негативно впливають на життя населення та на економічний розвиток країни в цілому. Результатом цього впливу є низька платоспроможність та низька ділова активність суб'єктів господарювання, які, як правило, призводять до нестабільного, а частіше, кризового стану фінансової діяльності, в тому числі підприємств харчової промисловості. Відмітимо, що виникненню безнадій- ної та сумнівної дебіторської заборгованості, несвоєчасне погашення заборгованості, зокрема, дебіторської, сприяє, як правило, низька платоспроможність підприємств та повернення заборгованості менше $100 \%$. Одним з головних чинників сприяння потрібного рівня ліквідності й платоспроможності підприємств, є ефективне ведення бухгалтерського обліку розрахунків з покупцями та замовниками за реалізацію готової продукції.

Також відмітимо, що до помилкових аналітичних розрахунків та висновків важливих показників підприємства, а саме, динаміка оборотності активів, ліквідність балансу та платоспроможності, ділова активність підприємства, в найближчому майбутньому, може призвести до відсутність або неповноти інформації про розрахунки з покупцями та замовниками у звітності підприємства.

Аналіз останніх публікацій 3 проблеми. 3 визначеної проблематики питання обговорюються як на науково-теоретичному рівні, так і на практиці. Актуальні питання організації обліку розрахунків 3 покупцями та замовниками за готову продукцію найбільш широко висвітлено в працях таких вітчизняних вчених, як С.Ф. Голова, Ф.Ф. Бутинця, В.І. Сфименка, А.М. Герасимовича, І.В. Жиглей, М.В. Кужельного, В.В. Сопка, В.Г. Линника, В.М. Пархоменка, I.I. Пилипенка, Л.К. Сук, В.Я. Савченка, В.М. Мурашка, 
М.Ф. Огійчука, В.В. Бабіча, В.В. Зотова та багато інших. Але, ряд важливих питань організації обліку готової продукції та розрахунків з покупцями та замовниками залишаються не висвітлені та потребують як теоретичної, так і практичної уваги та підтверджують актуальність даного дослідження.

Формування цілей дослідження. Мета роботи - розкриття сутності «дебіторська заборгованість» та «готова продукція», дослідження як теоретичних так і практичних аспектів організації обліку розрахунків з покупцями та замовниками за реалізацію готової продукції в сучасних умовах ринку - окреслила низку завдань:

- визначення сутності дебіторської заборгованості та готової продукції підприємства;

- аналіз дебіторської заборгованості та обсягу реалізації промислової продукції України у динаміці;
- обгрунтування теоретичних та практичних аспектів організації обліку розрахунків з покупцями та замовниками за реалізацію готової продукції.

Виклад основних результатів та їх обгрунтування. Організація обліку розрахунків з покупцями та замовниками за готову продукцію є одним 3 найважливіших процесів фінансово-господарської діяльності кожного підприємства, зокрема, харчової промисловості. Так, як для виготовлення готової продукції необхідні матеріали, то, відповідно, має бути або передоплата від покупців, або фінансова довіра покупцям. Стан розрахунків з покупцями та замовниками у фінансовій звітності відображає дебіторська заборгованість. Слід відмітити, що сутність поняття «дебіторська заборгованість» розкривається як в нормативно-законодавчій базі, так і в науково-економічній літературі (табл. 1).

Таблиця 1

Визначення сутності поняття «дебіторська заборгованість» за різними джерелами *

\begin{tabular}{|l|l|}
\hline \multicolumn{1}{|c|}{ Джерело/автор } & \multicolumn{1}{c|}{ Визначення } \\
\hline П(С)БО 10 [1] & $\begin{array}{l}\text { Дебітори - це юридичні та фізині особи, які внаслідок минулих подій забор- } \\
\text { гували підприємству певні суми грошових коштів, їх еквівалентів або інших } \\
\text { активів. Відповідно дебіторська заборгованість - це сума заборгованості дебі- } \\
\text { торів підприємству на певну дату. }\end{array}$ \\
\hline П(С)БО 13 [2] & $\begin{array}{l}\text { Дебіторська заборгованість - це безумовні права вимоги і зобов’язання визна- } \\
\text { ються фінансовими активами і фінансовими зобов' язаннями, якщо за умовами } \\
\text { контракту підприємство має право на отримання грошових коштів або бере на } \\
\text { себе зобов'язання сплатити грошові кошти. }\end{array}$ \\
\hline Голов С.Ф. [3] & $\begin{array}{l}\text { Дебіторська заборгованість - фінансовий актив, що є контрактним правом од- } \\
\text { нієї сторони отримати гроші й узгоджується з відповідним зобов’ язанням спла- } \\
\text { ти іншої сторони. }\end{array}$ \\
\hline $\begin{array}{l}\text { К.С. Сурніна, } \\
\text { С.О Іванов, М.Д. Білик [4-6] }\end{array}$ & $\begin{array}{l}\text { Дебіторська заборгованість - майно, що неоплачене контрагентами або готівка, } \\
\text { що вилучена з кругообігу оборотних засобів. }\end{array}$ \\
\hline $\begin{array}{l}\text { Р.М. Іванчук,О.А. Іванчук, } \\
\text { О.І. Агєєва [7, 8] }\end{array}$ & Дебіторська заборгованість - вилученні гроші, які винні контрагенти. \\
\hline
\end{tabular}

* Складено авторами на підставі джерел

Дефініція поняття «дебіторська заборгованість» згідно П(С)БО $10 €$ неповною, 3 нашої точки зору, оскільки не виявляє економічної сутності поняття. А автори К.С. Сурніна, С.О Іванов, М.Д. Білик розглядають готівку та майно як окремі частини. Але, готівка, відзначимо, що є частиною майна, розглядаючи це визначення 3 точки зору структури балансу. Наукові дослідження авторів Р.М. Іванчука, О.А. Іванчука, О.І. Агєєва стверджують, що дебіторська заборгованість - вилученні гроші. Проте, слід відмітити, що до формування дебіторської заборгованості входять не тільки грошові засоби.

Враховуючи своєчасну нестачу грошових коштів споживачів для свого розрахунку, суб'єкти підприємницької діяльності не рідко наражаються на ризик неповернення боргу [9] наданням комерційного кредиту, який, в свою чергу, значно поліпшує об'єми збуту. Таким чином, у колі науковців, питання безнадійної дебіторської заборгованості, що може виникнути в результаті погіршення фінансової ситуації дебітора, досі залишається складним в обліку розрахунків $з$ покупцями та замовниками [10]. На думку авторів [11] дебіторська заборгованість включає в себе усі вимоги підприємства до інших юридичних чи фізичних осіб щодо грошей, товарів чи послуг. Дебіторська заборгованість також є джерелом погашення власної кредиторської заборгованості, елементом оборотних активів, які можуть бути використанні у процесі функціонування [12].

Слід відмітити, що планом рахунків призначений для узагальнення інформації про розрахунки за операції стосовно відвантаження продукції, товарів, виконання робіт й послуг активний 36 рахунок «Розрахунки з покупцями та замовниками».

Податковий кодекс України підкреслює, що безнадійної дебіторської заборгованості, визначаються особливості покриття даного виду заборгованості банками і небанківськими фінансовими установами [13].

Таким чином, підсумовуючи поняття «дебіторська заборгованість» різними джерелами, можемо узагальнити і дати наступне визначення: «дебіторська заборгованість - це фінансовий або бартерний борг одного суб' єкта господарювання або фізичної особи 
перед іншим за отримані товари, роботи, послуги, готової продукції, тощо, який узгоджується з певними зобов'язанням його повернення у найближчому майбутньому.
Отже, покупці та замовники мають володіти фінансовими ресурсами для придбання готової продукції. Слід відзначити, що поняття «готова продукція» по різному трактується вітчизняними вченими (табл. 2).

Визначення сутності поняття «готова продукція» за різними джерелами*

\begin{tabular}{|c|c|}
\hline Джерело/автор & Визначення \\
\hline $\begin{array}{l}\text { Чебанова Н.В., } \\
\text { Єфіменко Т.I. [14, с. 369] }\end{array}$ & $\begin{array}{l}\text { Готова продукція - продукція, яка закінчила в обробці, пройшла випробування, прий- } \\
\text { мання, укомплектування згідно з умовами договорів із замовниками і відповідає тех- } \\
\text { нічними умовами і стандартами. }\end{array}$ \\
\hline Бутинець Ф.Ф. [15, с. 324] & $\begin{array}{l}\text { Готова продукція - повністю завершена обробкою, укомплектована, яка пройшла } \\
\text { неоххідні випробування (перевірки). Це виріб (або напівфабрикат), послуга, робо- } \\
\text { та, що пройшли всі стадії технологічної обробки на підприємстві, відповідають } \\
\text { затвердженим стандартам або умовам договору, прийняті технічним контролем } \\
\text { підприємства і здані на склад або замовникові - покупцеві згідно з діючим поряд- } \\
\text { ком прийняття продукції. }\end{array}$ \\
\hline $\begin{array}{l}\text { Глібко В.М., } \\
\text { Бущан О.П. [18, с. 112] }\end{array}$ & $\begin{array}{l}\text { Готова продукція - це матеріальний результат виробничої діяльності підприємст- } \\
\text { ва, коли запаси набувають нової якості. Крім випуску речової продукції, підпри- } \\
\text { єство може виконувати роботи для інших підприєств або надавати послуги. На } \\
\text { відміну від тієї, яка в обліку зазначається як готова продукція, цей вид продукції } \\
\text { називають «виконані роботи і послуги». Отже, продукція підприємства складаєть- } \\
\text { ся з готової продукції та виконаних робіт і послуг. }\end{array}$ \\
\hline Хом'як Р.Л. [19, с. 144] & $\begin{array}{l}\text { Готова продукція промислового виробництва - конкретні вироби, що пройшли всі } \\
\text { стадії технологічної обробки на цьому підприємстві, відповідають встановленим } \\
\text { стандартам чи технічним умовам, прийняті відділом технічного контролю і здані } \\
\text { на склад або безпосередньо замовнику. }\end{array}$ \\
\hline Шваб Л.І. [20, с. 23] & $\begin{array}{l}\text { Готова продукція - це запаси виробів на складі, обробка яких закінчена та які } \\
\text { пройшли випробування, приймання, укомплектовані згідно з умовами договорів із } \\
\text { замовниками й відповідають технічним умовам і стандартам. }\end{array}$ \\
\hline Ткаченко Н.М. [21, с. 671] & $\begin{array}{l}\text { Готова продукція - це продукція (виріб, напівфабрикат, робота, послуга), що пов- } \\
\text { ністю закінчена обробкою на даному підприємстві, пройшла всі стадії технічного } \\
\text { випробування (якщо вимагають відповідні ії особливості), приймання, укомплек- } \\
\text { тування згідно з умовами договорів із замовниками і відповідає технічним умовам } \\
\text { і стандартам, не потребує подальшої обробки на цьому підприємстві і здана на } \\
\text { склад. }\end{array}$ \\
\hline
\end{tabular}

* Складено авторами на підставі джерел

Відмітимо, що до визначення поняття «готова продукція» згідно наукових дослідженнях Бутинця Ф.Ф. схиляються і автори Вороніна В.А., Черниш В.В. [16, с. 75] та Сопко В.В. [17]. 3 вищенаведених дефініцій, на наш погляд, визначення Ткаченко Н. М. є більш узагальнене і відкриває суть поняття «готова продукція».

Господарські бухгалтерські операції, пов'язані зі змінами готової продукції, записуються на активному рахунку 26 «Готова продукція». Таким чином, в дебеті відображається оприбуткування готової продукції з цеху приватного виробництва за фактичною виробничою собівартістю або нормативною вартістю, а за кредитом - списання виробничої собівартості готової продукції.

Враховуючи той факт, що дебіторська заборгованість та готова продукція є одними 3 головних статей оборотного капіталу будь-якого суб'єкта господарської діяльності, слід розглянути їх стан в практичному аспекті на узагальнюючому рівні - державному. Отже, статистичне дослідження частки дебіторської заборгованості підприємств за 2011-2016 роки, свідчить про хвилеподібну динаміку на поча- ток, і за 2016 рік порівняно з 2015 роком збільшилась на $2,1 \%$ (рис. 1), хоча у вартісному виражені має тенденцію до збільшення (табл. 3). Слід відмітити, що за даними табл. 3 обсяг реалізованої промислової продукції в 2016 році порівняно з 2015 роком зменшився на $0,54 \%$.

Підсумовуючи вищевикладене, першочерговими завданнями дієвої організації обліку реалізації готової продукції покупцям та замовникам, на нашу думку, $є$ :

- своєчасне прийняття замовлення від покупця;

- періодична перевірка за випуском готової продукції, станом іiі нагромадження в місцях збереження;

- вчасне та правильне документування оформлення продукції, яка відвантажена та відпущена; - контроль за дотримання плану угод замовлень за об'ємом та асортиментом проданої продукції;

- вчасне і достовірне визначення підсумків від збуту продукції (робіт, послуг) та їх облік; - контроль за наданою відстрочкою платежу. 


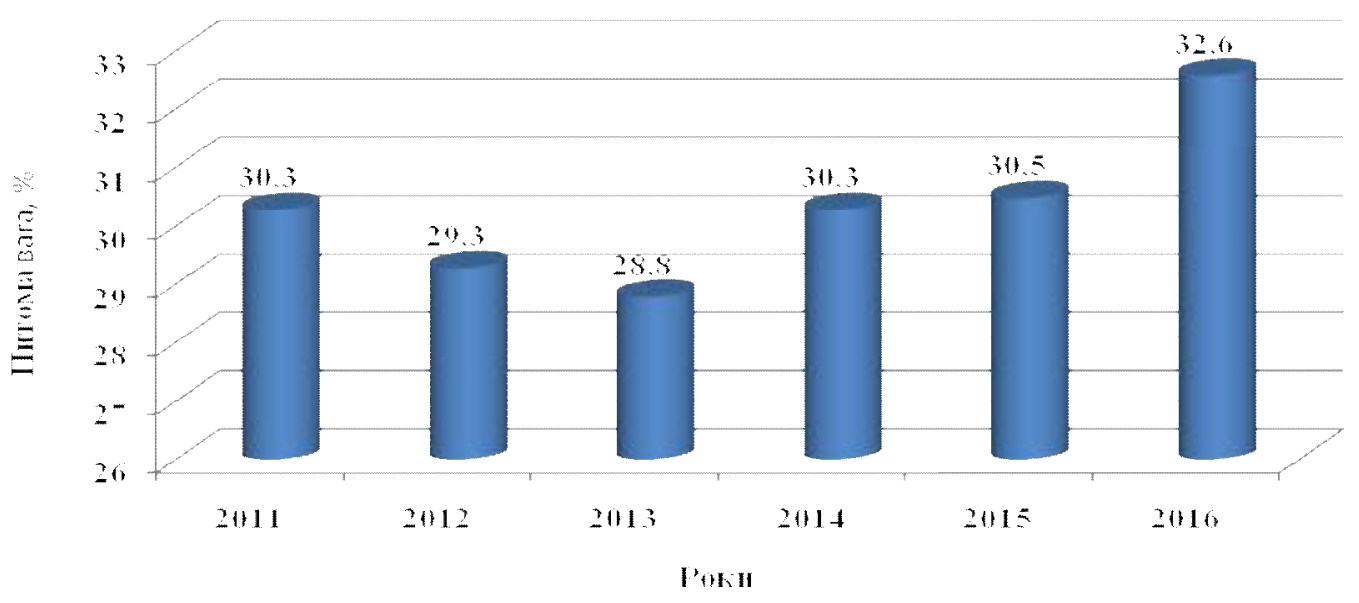

Рис. 1. Питома вага дебіторської заборгованості підприсмств за економічним видом діяльності промисловість*

*сформовано авторами за [22-23]

Таблиця 3

Обсяг реалізованої промислової продукції та дебіторська заборгованість підприємств України*

\begin{tabular}{|c|c|c|c|c|c|c|}
\hline \multirow{2}{*}{ Показники } & \multicolumn{6}{|c|}{ Роки } \\
\hline & 2011 & 2012 & 2013 & 2014 & 2015 & 2016 \\
\hline $\begin{array}{l}\text { 1. Обсяг реалізованої промис- } \\
\text { лової продукції, млн. грн. }\end{array}$ & 1331887,6 & 1400680,2 & 1354130,1 & 1428839,1 & 1776603,7 & 1767093,3 \\
\hline $\begin{array}{l}\text { 2. Обсяг виробництва харчо- } \\
\text { вих продуктів, напоїв і тютю- } \\
\text { нових виробів, млн. грн. }\end{array}$ & 222387,8 & 254459,9 & 261783,7 & 302391,9 & 398023,2 & 381445,1 \\
\hline $\begin{array}{l}\text { 3. Питома вага обсягу вироб- } \\
\text { ництва харчових продуктів, } \\
\text { напоїв і тютюнових виробів, \% }\end{array}$ & 16,7 & 18,2 & 19,3 & 21,2 & 22,4 & 21,6 \\
\hline $\begin{array}{l}\text { 4. Дебіторська заборгованість } \\
\text { підприємств, млн. грн. }\end{array}$ & 1499971,5 & 1701397,3 & 1778103,7 & 1962772,1 & 2517203,5 & 2409043,7 \\
\hline $\begin{array}{l}\text { 5. Дебіторська заборгованість } \\
\text { підприємств за економічним } \\
\text { видом діяльності промисло- } \\
\text { вість, млн. грн. }\end{array}$ & 454465,8 & 498079,0 & 512093,2 & 595111,0 & 767422,2 & 786022,6 \\
\hline $\begin{array}{l}\text { 6. Питома вага дебіторської } \\
\text { заборгованості підприємств за } \\
\text { економічним видом діяльності } \\
\text { промисловість, \% }\end{array}$ & 30,3 & 29,3 & 28,8 & 30,3 & 30,5 & 32,6 \\
\hline
\end{tabular}

*Складено авторами на підставі джерел [22,23]

Висновки та перспективи подальших досліджень. Проведені дослідження підтверджують важливість розуміння сутності категорії «готова продукція» та «дебіторська заборгованість», оскільки вони займають вагому частку в структурі оборотного капіталу кожного підприємств. В результаті дослідження ми визначили, що «дебіторська заборгованість» - це фінансовий або бартерний борг одного суб'єкта господарювання або фізичної особи перед іншим за отримані товари, роботи, послуги, готової продукції, тощо, який узгоджується 3 певними зобов'язанням його повернення у найближчому майбутньому. А, «готова продукція» - це вироби, які не потребують подальшого, особливо, технічного оброблення, мають завершену зовнішність і готові до збуту.

Статистичні дослідження питомої ваги дебіторської заборгованості підприємств за економічним видом діяльності промисловість за останні роки свід- чать про тенденцію до збільшення. I, це явище можна розглядати, з однієї сторони, негативно, бо збільшується частина безнадійної дебіторської заборгованості. А, з іншого боку, це свідчить про збут продукції 3 різними методами розрахунку, наприклад умовою відстрочки.

В умовах сьогодення однією зі складових успішної організації обліку і оцінки наявності та зміни розрахунків $з$ покупцями та замовниками за реалізацію готової продукції є підвищений рівень застосування облікових даних для оцінювання та контролю запобігання невиплаченої дебіторської заборгованості. Слід відзначити, що для будь-якого підприємства готова продукція (товар, послуга) визначена відповідно до виду діяльності. I тому, строки дебіторської заборгованості відрізняються, що свідчить про необхідність аналітичного (індивідуального) обліку розрахунків з покупцями та замовниками. 


\section{Література}

1. Положення (стандарт) бухгалтерського обліку 10 «Дебіторська заборгованість» від 08.10.1999 року № 237 : за станом на 09.08.2013 p. [Електронний ресурс]. - Режим доступу: http://zakon2.rada.gov.ua/laws/show/z0725-99.

2. Положення (стандарт) бухгалтерського обліку 13 «Фінансові інструменти» від 30.11 .2001 року № 559 : за станом на 09.08.2013 р. [Електронний ресурс]. - Режим доступу: https://zakon.help/law/559/

3. Голов С.Ф. Бухгалтерський облік за міжнародними стандартами: приклади та коментарії: [практ. посіб.] / С.Ф. Голов, В.М. Костюшенко. - К.: Лібра, 2001. - 670 с.

4. Сурніна К.С. Удосконалення обліку дебіторської і кредиторської заборгованості промислових підприємств: автореф. дис. на здобуття наук. ступеня к.е.н.: 08.06.04 «Бухгалтерський одлік, аналіз та аудит» / К.С. Сурніна. - Луганськ, 2002. - 19с.

5. Іванов Є.О. Класифікація факторів, що впливають на загальний рівень дебіторської заборгованості підприємства / С.О. Іванов // Вісник МСУ. - 2005. - Вип.1-2, Т.VIII. - С. 35-38;

6. Білик М.Д. Управління дебіторською заборгованістю підприємств / М.Д. Білик // Фінанси України. - 2003. - №12. - С. 24-36.

7. Іванчук Р.М. Деякі міркування щодо методологічних засад формування інформації про дебіторську заборгованість / Р.М. Іванчук, О.А. Іванчук// Економічний вісник Донбасу. - 2005. - №1. - С. 11-22;

8. Агеева Е.И. Кредитная политика как инструмент управления дебиторской задолженностью / Е. И. Агеева //Финансовый менеджмент. - 2004. -№6. - С.22-23.

9. Шестерікова В.В. Обліковий аспект розрахунків з покупцями та замовниками в аграрних підприємствах / В.В. Шестерікова, С.В. Тивончук // Економічні науки. Сер. : Облік і фінанси. - 2013. - Вип. 10(4). - С. $420-425$.

10. Гнатенко Є.П. Нормативно-правові засади обліково-аналітичного забезпечення розрахунків 3 покупцями та замовниками / С.П. Гнатенко, О.С. Горячковська // Молодий вчений. - 2016. - № 10. - С. 351-354.

11. Велш Глен А. Основи фінансового обліку / Велш Глен А., Шорт Деніел Г.; пер. 3 англ. О. Мінін, О. Ткач. - К.: Основи, 1997. - 943с.

12. Дергалюк Б.В. Управління дебіторською заборгованістю як інструмент забезпечення економічної безпеки підприємств в сучасних умовах [Електронний ресурс] / Б.В. Дергалюк // - Режим доступу: http://www.economy.nayka.com.ua/pdf/9 2015/45.pdf

13. Податковий кодекс України від 02.12.2010 року № 2755-VI: за станом на 01.01.2018 р. [Електронний pecypc]. - Режим доступу: http://zakon5.rada.gov.ua/laws/show/2755-vi

14. Чебанова Н.В. Фінансовий облік: [підруч.] / Н.В.Чебанова, Т.І. Єфіменко. - К.: ВЦ «Академія», 2007. - 704c.

15. Бутинець Ф.Ф. Бухгалтерський фінансовий облік: [підруч. для студ. спец. «Облік і аудит» вищих навчальних закладів] / Ф.Ф. Бутинець. - [7-ме вид., доп. і перероб.]. - Житомир: Рута, 2006. - С. 832.

16. Вороніна В.Л. Особливості документального відображення руху готової продукції / В.Л. Вороніна, В.В. Черниш // Кримський економічний вісник. - 2013. - Частина I. - 277 с.

17. Сопко В.В. Бухгалтерський облік [Електронний ресурс] / В.В. Сопко. - Режим доступу: http://fingal.com.ua/content/view/780/35/1/3/ C. 224 .

18. Глібко В.М. Судова бухгалтерія: [підруч.] / В.М. Глібко, О.П. Бущан. - К. : Юрінком Інтер, 2006. -

19. Бухгалтерський облік в Україні : [навч. посіб.] / [Хом’як Р.Л., Партин Г.О., Корягін М.В. та ін.; за ред. Р.Л. Хом’яка. - [2-е вид.]. - Львів : «Інтелект-Захід», 2003. - 820 с.

20. Шваб Л.І. Економіка підприємства: [навч. посіб.] / Л.І. Шваб. - К.: Каравела, 2005. - 568 с.

21. Ткаченко Н. М. Бухгалтерський фінансовий облік, оподаткування і звітність: [підручник] / Н. М. Ткаченко. - [3-те вид. доп. і перероб. ] . - К.: Алерта, 2008. - 926 с.

22. Обсяг реалізованої промислової продукції за видами діяльності за 2011-2016 роки / Державна служба статистики України [Електронний ресурс]. - Режим доступу: http://www.ukrstat.gov.ua.

23. Оборотні активи підприємств за видами економічної діяльності за 2011-2016 роки / Державна служба статистики України - [Електронний ресурс]. - Режим доступу: http://www.ukrstat.gov.ua.

Стаття надійшла 7.02.2018

Стаття прийнята до друку 21.02.2018

Доступно в мережі Internet 31.03.2018 
Маркова Т.Д.

кандидат экономических наук, старший преподаватель E-mail: markova.tetiana17@gmail.com
Стрепенюк М.Н. магистрант

E-mail: marina.strepenyuk@ukr.net

\author{
Рымарь A.A. \\ магистрант \\ кафедра учета и аудита \\ Одесская национальная академия пищевых технологий \\ ул. Канатная, 112, г. Одесса, Украина, 65039 \\ E-mail: anna1995@te.net.ua
}

\title{
АСПЕКТЫ УЧЕТА РАСЧЕТОВ С ПОКУПАТЕЛЯМИ И ЗАКАЗЧИКАМИ ЗА ГОТОВУЮ ПРОДУКЦИЮ В СОВРЕМЕННЫХ УСЛОВИЯХ
}

В статье рассматривается сущность понятия «дебиторская задолженность», «готовая продукция», теоретические и практические аспекты организации учета расчетов с отечественными покупателями и заказчиками за реализацию готовой продукции на предприятии.

В результате исследования определено, что возникновению сомнительной и безнадежной дебиторской задолженности и несвоевременное погашение дебиторской задолженности способствует, как правило, низкая платежеспособность предприятий и возврата задолженности меньше 100\%. Одним из главных факторов поддержания необходимого уровня ликвидности и платежеспособности предприятий, является эффективное ведение бухгалтерского учета расчетов с покупателями и заказчиками за реализацию готовой продукции.

Проведен анализ дебиторской задолженности и объем реализованной промышленной продукции Украины. Статистическое исследование доли дебиторской задолженности предприятий за 2011-2016 годы, свидетельствует о волнообразную динамику на начало, и за 2016 по сравнению с 2015 годом увеличилась на 2,1\%, хотя в стоимостном выражение имеет тенденцию к увеличению. Следует отметить, что объем реализованной промышленной продукции в 2016 году по сравнению с 2015 годом уменьшился на 0,54\%.

Проведенные исследования подтверждают важность понимания сущности категории «готовая продукция» и «дебиторская задолженность», поскольку они занимают весомую долю в структуре оборотного капитала каждого предприятия. В современных условиях одной из составляющих успешной организации учета и оценки наличия и движения расчетов с покупателями и заказчиками за реализацию готовой продукции является повышенный уровень применения учетных данных для оценки и контроля предотвращения невыплаченной дебиторской задолженности. Следует отметить, что для любого предприятия готовая продукция (товар, услуга) определена в соответствии с видом деятельности. И потому, сроки дебиторской задолженности отличаются, что свидетельствует о необходимости аналитического (индивидуального) учета расчетов с покупателями и заказчиками.

Ключевые слова: дебиторская задолженность, учет расчетов с покупателями и заказчиками, готовая продукция, безнадежная дебиторская задолженность.

\begin{tabular}{|c|c|}
\hline $\begin{array}{c}\text { Markova T. } \\
\text { Ph. D., Assistant }\end{array}$ & $\begin{array}{c}\text { Strepenyuk M. } \\
\text { Undergraduate }\end{array}$ \\
E-mail: markova.tetiana17@gmail.com & E-mail: marina.strepenyuk@ukr.net \\
\hline $\begin{array}{c}\text { Rymar H. } \\
\text { Undergraduate }\end{array}$ \\
Department of Accounting and Auditing \\
Odesa National Academy of Food Technologies \\
Kanatna str., 112, Odesa, Ukraine, 65039 \\
E-mail: anna1995@te.net.ua
\end{tabular}

\section{ASPECTS OF THE ACCOUNT OF CALCULATIONS WITH BUYERS AND CUSTOMERS FOR FINISHED PRODUCTS IN MODERN CONDITIONS}

The article deals with the essence of the concept of "accounts receivable", "finished products", the theoretical and practical aspects of the organization of the account of calculations with domestic buyers and customers for the realization of finished products in the enterprise.

The study determined that the emergence of doubtful and hopeless accounts receivable and late payment of receivables is contributed, as a rule, by low solvency of companies and debt repayment is less than $100 \%$. One of the main factors supporting the necessary level of liquidity and solvency of enterprises is 
the effective accounting maintenance of settlements with buyers and customers for the sale of finished products.

The analysis of accounts receivable and the volume of sold industrial products of Ukraine has been carried out. The statistical study of the proportion of accounts receivable of enterprises for the years 20112016, shows a wave-like dynamics at the beginning of, and during 2016 compared to 2015 increased by $2.1 \%$, while in terms of value tends to increase. It should be noted that the volume of sold industrial products in 2016 compared to 2015 decreased by $0.54 \%$.

The conducted studies confirm the importance of understanding the essence of the category "finished goods" and "receivables", as they occupy a significant share in the working capital structure of each enterprise. In modern conditions of one of the components of a successful organization of accounting and evaluating of the presence and movement of settlements with buyers and customers for the realization of finished products is the increased level of application the accounting date to evaluate and monitor the prevention of unpaid receivables. It should be noted that for any enterprise, finished products (goods, services) are determined in accordance with the type of activity. And therefore, the terms of the receivables differ, which indicates the need for analytical (individual) accounting of payments with buyers and customers.

Keywords: receivables, accounting of settlements with buyers and customers, finished goods, bad accounts receivable.

\section{References}

1. Polozhennia (standart) bukhhalterskoho obliku 10 «Debitorska zaborhovanist» vid 08.10.1999 roku № 237 : Za stanom na 09.08.2013 r. (2013). Retrieved from http://zakon2.rada.gov.ua/laws/show/z0725-99.

2. Polozhennia (standart) bukhhalterskoho obliku 13 «Finansovi instrumenty» vid 30.11 .2001 roku № 559 : Za stanom na 09.08.2013 r. (2013). Retrieved from https://zakon.help/law/559/

3. Holov, S. F., \& Kostiushenko, V. M. (2001). Bukhhalterskyi oblik za mizhnarodnymy standartamy: Pryklady ta komentarii. K.: Libra.

4. Surnina, K. S. (2002). Udoskonalennia obliku debitorskoi i kredytorskoi zaborhovanosti promyslovykh pidpryiemstv. Luhansk.

5. Ivanov, Ye. O. (2005). Klasyfikatsiia faktoriv, shcho vplyvaiut na zahalnyi riven debitorskoi zaborhovanosti pidpryiemstva. Visnyk MSU, 8(1-2), 35-38.

6. Bilyk, M. D. (2003). Upravlinnia debitorskoiu zaborhovanistiu pidpryiemstv. Finansy Ukrainy,(12), 24-36.

7. Ivanchuk, R. M., \& Ivanchuk, O. A. (2005). Deiaki mirkuvannia shchodo metodolohichnykh zasad formuvannia informatsii pro debitorsku zaborhovanist. Ekonomichnyi Visnyk Donbasu,(1), 11-22.

8. Ageeva, E. I. (2004). Kreditnaya politika kak instrument upravleniya debitorskoy zadolzhennostyu. Finansovyiy Menedzhment, (6), 22-23.

9. Shesterikova, V. V., \& Tyvonchuk, S. V. (2013). Oblikovyi aspekt rozrakhunkiv z pokuptsiamy ta zamovnykamy v ahrarnykh pidpryiemstvakh. Ekonomichni Nauky, (10 (4)), oblik i finansy, 420-425.

10. Hnatenko, Ye. P., \& Horiachkovska, O. S. (2016). Normatyvno-pravovi zasady oblikovo-analitychnoho zabezpechennia rozrakhunkiv z pokuptsiamy ta zamovnykamy. Molodyi Vchenyi, (10), 351-354.

11. Velsh, H. A., \& Short, D. H. (1997). Osnovy finansovoho obliku (O. Minin \& O. Tkach, Trans.). K.: Osnovy.

12. Derhaliuk, B. V. (2015). Upravlinnia debitorskoiu zaborhovanistiu yak instrument zabezpechennia ekono-
michnoi bezpeky http://www.economy.nayka.com.ua/pdf/9_2015/45.pdf

13. Podatkovyi kodeks Ukrainy vid 02.12.2010 roku № 2755-VI: Za stanom na 01.01.2018 r. (2018). Retrieved from http://zakon5.rada.gov.ua/laws/show/2755-vi

14. Chebanova, N. V., \& Yefimenko, T. I. (2007). Finansovyi oblik. K.: VTs «Akademiia».

15. Butynets, F. F. (2006). Bukhhalterskyi finansovyi oblik (7th ed.). Zhytomyr: Ruta.

16. Voronina, V. L., \& Chernysh, V. V. (2013). Osoblyvosti dokumentalnoho vidobrazhennia rukhu hotovoi produktsii. Krymskyi Ekonomichnyi Visnyk, 1st ser.

17. Sopko, V. V. (2000). Bukhhalterskyi oblik. Retrieved from http://fingal.com.ua/content/view/780/35/1/3/

18. Hlibko, V. M., \& Bushchan, O. P. (2006). Sudova bukhhalteriia. K.: Yurinkom Inter.

19. Khom'iak, R. L., Partyn, H. O., \& Koriahin, M. V. (2003). Bukhhalterskyi oblik v Ukraini (2nd ed.) (R. L. Khom'iak, Ed.). Lviv: «Intelekt-Zakhid».

20. Shvab, L. I. (2005). Ekonomika pidpryiemstva. K.: Karavela.

21. Tkachenko, N. M. (2008). Ukhhalterskyi finansovyi oblik, opodatkuvannia i zvitnist (3rd ed.). K.: Alerta.

22. Obsiah realizovanoi promyslovoi produktsii za vydamy diialnosti za 2011-2016 roky / Derzhavna sluzhba statystyky Ukrainy. Retrieved from http://www.ukrstat.gov.ua.

23. Oborotni aktyvy pidpryiemstv za vydamy ekonomichnoi diialnosti za 2011-2016 roky / Derzhavna sluzhba statystyky Ukrainy. Retrieved from http://www.ukrstat.gov.ua. 